\title{
Hangi Öğrenciler Daha Uyumlu? Üniversiteye Uyumun Bazı Demografik Faktörlere Göre İncelenmesi ${ }^{1}$ \\ DOI: $10.26466 /$ opus.773534
}

*

\author{
Evren Erzen* - Nilüfer Özabac1 ** \\ * Dr. Öğr. Üyesi, Artvin Çoruh Üniversitesi \\ E-Posta: evrenerzen@hotmail.com \\ ORCID: $\quad$ 0000-0001-9726-2688 \\ **Prof. Dr., Yeditepe Üniversitesi \\ E-Posta: niluferozabaci@hotmail.com \\ ORCID: $\underline{0000-0001-6237-1921}$
}

\begin{abstract}
Öz
Bu araştırmada cinsiyet, öğrenim görülen fakülte ve sını düzeyi değişkenlerinin, üniversiteye farkh düzeylerdeki uyumda farklılaşmaya sebep olup olmadığı ele alınmış̧ır. Araştırma, değişkenler arası ilişkileri belirlemek amacıyla ilişkisel desende tasarlanmıştır. Katılımcılar altı farklı fakültede öğrenim gören 992 üniversite öğrencisinden oluşmaktadır. Katılımciların 377'si erkek (\%38), 615'i kadındır (\%62). Sonuçlar kız öğrencilerin erkek öğrencilere oranla daha iyi uyum sağladığın göstermektedir. Fakülte değişkenine yönelik analizler arkadaş ilişkilerinde uyum açısından eğitim, iktisat ve işletme, ilahiyat, mimarlık-mühendislik ile fen-edebiyat; akademik uyum açısından ilahiyat, eğitim ve tıp; üniversiteye genel uyum sağlama açısından ilahiyat ve tıp fakültesi öğrencilerinin avantajlı olduğunu göstermektedir. Sını düzeyleri açısından yapılan analizler ikinci sınıf öğrencilerinin arkadaş ilişkilerinde uyum bağlamında risk grubunda olduğunu, ikinci sını öğrencilerinin uyum sorunu yaşama potansiyellerinin diğer sınf düzeylerinden daha fazla olduğunu göstermektedir. Ulaşılan sonuçlar literatür ışı̆̆ııda tartışılmışıtır.
\end{abstract}

Anahtar Kelimeler: Üniversiteye uyum, fakülte, sinıf düzeyi, cinsiyet

\footnotetext{
${ }^{1}$ Bu çalışma Prof. Dr. Nilüfer ÖZABACI danışmanlığında Evren ERZEN tarafından hazırlanan doktora tezinin verilerinin bir kısmı kullanılarak hazırlanmıştır.
} 


\title{
Which Students Are More Adjusted? Examination Of University Adjustment In Terms Of Some Demographic Factors
}

\begin{abstract}
In this study, it was examined whether the variables of gender, faculty and grade level of education caused differentiation in university adaptation at different levels. The research was designed in a correlational design to determine the relationships between variables. Participants consisted of 992 university students from six different faculties. 377 of the participants were male (38\%) and 615 were female (62\%). The results show that female students adapt better than male students. The analysis of the faculty variable faculty variable shows that in terms of friendship adjustment, faculties of education, economics and administrative sciences, theology, engineering and architecture and science and letters seem to be advantageous; theology, education and medicine in terms of academic adjustment; in terms of general adjustment to the university, theology and medical faculty students seem to be advantageous. Analyzes in terms of grade levels revealed that second grade students were in the risk group in terms of adjustment in their friendship relationships, and the potential of second grade students to have adjustment problems was higher than other grade levels. The results were discussed in the light of literature.
\end{abstract}

Keywords: Adjustment to university, faculty, grade level, gender 


\section{Giriş}

Üniversite yaşamı insanların yükseköğrenimlerini tamamladıkları bir dönem olmanın ötesinde ailelerinden ayrı kaldıkları, yaşamın güçlükleriyle yüz yüze geldikleri önemli bir zaman dilimidir. Bu sebeple bireyler; üniversite yaşaminda gerek kendisinden, gerekse çevresinden kaynaklanan faktörlere dayalı uyum sorunları yaşayabilmektedirler.

Üniversiteye uyum sorunlarının nedenlerine odaklanan araştırmalara bakıldığında demografik değişkenlerin ön planda olmadığı, bunun yerine bireyin kişisel özelliklerinin yer aldığı araştırmaların ağırlıkta olduğu görülmektedir. Söz konusu kişisel özelliklerle üniversiteye uyumun ilişkisi hakkında fikir sahibi olmaya yardımcı olacak çok sayıda araştırma bulunmaktadır (Gómez, Alfredo ve Glass, 2014; Kalsner ve Pistole, 2015; Leong ve diğg., 2017). Bununla birlikte çevresel faktörlerin de üniversiteye uyum üzerinde etkili olabildiğine ilişkin ipuçları bulunmaktadır. Örneğin farklı fakültelerdeki öğrencilerin üniversiteye uyum düzeylerinin değişebildiği (Bökeoğlu, 2007; Karahan ve diğ., 2005), farklı okul çevreleri öğrencinin uyum düzeyine etki edebildiği (Murray-Harvey ve Slee, 2010) bilinmektedir. Türkiye'de üniversiteye giriş puanları açısından bakıldığında yıllardır en yüksek puanlarla giriş yapılan tıp fakülteleri (YÖK, 2019a) ile nispeten çok daha düşük puanlarla öğrenci alımı yapan iktisadi ve idari bilimler fakültelerinin (YÖK, 2019b) aynı çevresel koşullara sahip olmaları pek mümkün görünmemektedir. Bununla birlikte öğrencilerin sinıf düzeyleri de üniversiteye uyum düzeylerinin belirlenmesinde önemli bir etken konumundadır. Uyum sorunları açısından birinci sınıf öğrencilerini ön plana çıkaran çalışmaların (Bülbül ve Güvendir, 2014; Hinkle, 2004) yanı sıra az sayıda farklı sınıf düzeylerini inceleyen çalışma bulunmaktadır (Reyes, 2011; Sülek Şanlı, 2015). Bu durum, farklı sınıf düzeylerinde ve fakültelerde yaşanmakta olan uyum sorunlarının gözden kaçırılması ve müdahale programlarında bu faktörlerin göz ardı edilmesi riskini barındırmaktadır. Bu açıdan üniversiteye uyumun belirlenmesinde öğrenim görülen fakültelerin ve sinıf düzeylerinin göz önünde bulundurulması önemlidir. Son olarak çalışmada başlı başına uyum düzeyine etki eden bir faktör olan cinsiyet faktörü yer almaktadır. Bilindiği üzere kadınların erkeklere göre sahip oldukları biyolojik ve hormonal farklılıkların büyük ölçüde psikolojik sonuçları bulunmakta ve bu durum da kadınlarla erkeler arasında uyum becerileri açısından farklılaşmaya sebep olmaktadır (Brizendine, 2014b, 2014a). 
Öte yandan kadınlar erkeklerden farklı yaşayış tarzlarına sahip olduğu gibi erkeklere etki edenlerden daha farklı sosyal faktörlere maruz kalabilmektedirler (Sancar, 2014). Dolayısıyla kadınlarla erkekler arasında uyum açısından farklılaşma olması beklenen bir durumdur. Fakat bu farklılaşmanın üniversiteye uyumun hangi alt basamağında ve özellikle hangi uyum düzeyinde gerçekleştiğine dair henüz bir araştırmaya rastlanmamıştır. Bu sebeple bu çalışmadan elde edilecek bulguların, önceki araştırmaların sonuçlarını tamamlayıcı nitelikte olacağı düşünülmektedir.

Literatürde üniversiteye uyum becerileri ile demografik faktörler arasındaki ilişkiyi ele alan çalışmalara bakıldığında barınma sorunu (Filiz ve Çemrek, 2006; Rienties, Beausaert, Grohnert, Niemantsverdriet ve Kommers, 2012), sosyal olanakların yetersizliği (Karahan, Sardoğan, Özkamalı ve Dicle, 1999; Sevüktekin, Nargeleçekenler ve Çetin, 2012) ve maddi imkânsızlıklar (Güçlü, 1995) gibi faktörlerin etkilerinin ele alındı̆̆ı gözlenmektedir. Bununla birlikte özellikle yurtdışı araştırmalarda çok uluslu öğrenci alımı yapan üniversitelerin dil uyuşmazlığı (Yusoff, 2012) gibi güçlüklere bağlı uyum sorunları yaşandığına dair bulgular elde edilmiştir. Konuya psikolojik danışma ve uyum programları açısından bakıldığında tüm bu veriler, oluşturulacak müdahale ve uyum programlarının geliştirilmesinde büyük öneme sahip olacaktır. Çünkü yalnızca bireyle doğrudan ilişkili öz-yeterlik (Thomas ve diğ., 2016), sosyal destek (Halamandaris ve Power, 1997) ve bağlanma stili (Bernier, Larose, Biovin ve Soucy, 2004) gibi faktörler değil, kişiye dolaylı olarak etki eden bu gibi çevresel faktörler de bireyin uyum sürecine olumlu veya olumsuz özellikleri sebebiyle önem arz etmektedir. Bu noktada öğrencilerin öğrenim gördükleri sınıf düzeyleri (İkiz, Asıcı, Savcı ve Yörük, 2015) ve fakülte (Mercan ve Yıldız, 2011) gibi faktörlerin az sayıda çalışma ile incelendiği görülmektedir. Bu eksiklik, uyum sorunlarına yönelik geliştirilecek olan psiko-eğitim programlarının olası etkilerinin göz ardı edilmesi anlamına gelebilir. Dolayısıyla üniversiteye uyum düzeyine etki edebilecek sayısız değişken bulunmaktayken bu konuda ne kadar farklı değişkene ilişkin veri elde edilirse çözüme yönelik geliştirilecek programlara o kadar katkı sağlanmış olacaktır. Bu sebeple öğrenim görülen fakülte, sınıf düzeyi ve cinsiyete ilişkinin bulguların, literatürdeki bulguların çeşitlenmesine ve zenginleşmesine katkı sağlayacağı düşünülmektedir. Ayrıca çalışma kapsamında elde edilen verilerin düşük, orta ve yüksek olmak üzere üç farklı uyum düzeyinde elde 
edilmiş olması, araştırmacılara tüm bu faktörlerin farklı uyum düzeylerindeki etkilerini karşılaştırma olanağı vereceği düşünülmektedir. Bu sebeple bu çalışmada incelenen değişkenler ve elde edilen verilerin üç farklı uyum düzeyinde ele alınmış olması önemlidir.

Bu çalışmada üniversite öğrencilerinin cinsiyet, öğrenim gördükleri fakülte ve sinıf düzeylerine göre üniversiteye uyum becerilerinin farklılaşmaya sebep olup olmadığının belirlenmesi amaçlanmıştır. Bu doğrultuda üniversite öğrencilerinin uyum düzeyleri belirlenerek her bir uyum düzeyinde farklılaşma olup olmadığı ayrı ayrı sınanmıştır.

\section{Yöntem}

\section{Çalışmanın Deseni}

Çalışmada üniversiteye uyum faktörü bağımlı; cinsiyet, fakülte ve sınıf düzeyi değişkenleri bağımsız değişkenler olarak belirlenmiştir. Bağımsız ve kategorik nitelikteki değişkenlerin bağımlı değişkende farklılaşmaya neden olup olmadığının belirlenmesi amaçlanmıştır. Bu sebeple çalışmada ilişkisel desenden faydalanılmıştır. İliş̧kisel desen, değişkenler arasındaki bağların açığa çıkartılması ve daha iyi anlaşılması amacıyla kullanılmakta olan nicel yaklaşıma dayalı bir desendir (Lodico, Spaulding ve Voegtle, 2006). İlişkisel desenler iki veya daha fazla değişken arasında, elde edilen puanların çıarımsal sonuç elde etmeye olanak sağlamaktadır (Creswell, 2012). Bu sebeple bu çalışmada bağımlı değişkenin bağımsız değişkenler tarafından farklılaşıp farklılaşmadığının belirlenmesi amacıyla ilişkisel desen kullanılmıştır.

\section{Katılimcilar Ve Prosedür}

Çalışmanın evreni Türkiye'de bir üniversitenin 21.876 kayıtlı lisans öğrencisi olarak belirlenmiş ve bu üniversiteye bağlı altı farklı fakültenin dört farklı sınıf düzeyinden kolay ulaşılabilir örnekleme yöntemiyle veriler toplanmıştır. Çalışma kapsamında 1035 katılım cıdan veri toplanmış, z puanlarının incelenmesi sonucunda uç değerlere sahip olduğu belirlenen veriler çıkartılarak 992 kişilik veri seti elde edilmiştir. Katılımcılar, doldurulacak ölçek ve bilgi formu hakkında bilgilendirilmiş ve 40 dakikalık bir ders saati içerisinde uygulama sonlandırılmıştır. Katılımcıların 377'si erkek (\%38), 615'i kadındır (\%62). Ayrıca katılımcıların 223'ü (\%22.5) birinci, 306'sı ikinci (\%30.8), 262'si üçüncü (\%26.4) ve 201'i dördüncü sınıfa (\%20.3) devam etmektedir. Fakülte bazında 
ise öğrencilerin 170'i (\%17.1) fen-edebiyat, 154'ü (\%15.5) tıp fakültesi, 124'ü (\%12.5) mimarlık mühendislik, 178'i (\%17.9) iktisat ve işletme, 193'ü (\%19.5) ilahiyat ve 173'ü (\%17.4) eğitim fakültesi öğrencilerinden oluşmaktadır.

Katılımcılara elde edilecek tüm verilerin gizli tutulacağı ve yalnızca bilimsel araştırma amacıyla kullanılacağı ve tüm katılımcıların istekleri doğrultusunda araştırmadan çekilme hakları olduğu, gönüllü olarak katılım sağlamalarının beklendiği belirtilmiş ve herhangi bir teşvik sağlanmamıştır.

\section{Veri Toplama Araçları}

Üniversite Uyum Ölçeği: Üniversite Uyum Ölçeği, yazarın doktora araştırması kapsamında geliştirilmiştir. Üniversite öğrencilerinin uyum becerilerini Arkadaş İlişkisinde Uyum ve Akademik Uyum olmak üzere iki alt boyutla ele alan ölçek, 1'den (kesinlikle katılmıyorum) 5'e (kesinlikle katılıyorum) kadar derecelendirilmiş 5 'li Likert tipinde ve 11 maddelidir. Ölçeğin geçerliğine ilişkin elde edilen doğrulayıc faktör analizi değerleri $\chi^{2} / \mathrm{sd}=1.41, \mathrm{RMSEA}=$ $.04, \mathrm{GFI}=.95, \mathrm{CFI}=.98$ ve NNFI = .97'dir. Ölçeğin güvenirliğine ilişkin Cronbach Alpha iç tutarlılık katsayıları ise Arkadaş İlişkisinde Uyum boyutu için .83, Akademik Uyum boyutu için .82 ve ölçeğin bütünü için .82'dir.

Kişisel Bilgi Formu: Araştırmacı tarafından hazırlanmış olan kişisel bilgi formunda katılımciların cinsiyet, öğrenim gördükleri fakülte ve sınıf düzeyine ilişkin sorular yer almaktadır.

\section{Veri analizi}

Üniversite öğrencilerinin farklı uyum düzeylerinde hangi faktörlerden etkilendiğinin belirlenmesi amaciyla Kruskal Wallis ve Mann Whitney U testlerinden yararlanılmıştır. Üniversite öğrencilerinin sahip olduğu uyum düzeylerinin belirlenmesi içinse öncelikle uyum ölçeğinden alınan minimum ve maksimum puanlar belirlenmiştir. Sonrasında her bir alt boyut için ortalama ve standart sapma puanları belirlenerek uyum düzeyleri tespit edilmiştir. Sonuç olarak düşük, orta ve yüksek uyum düzeylerine sahip olduğu belirlenen gruplardan arkadaş ilişkisinde uyum için 131, 642 ve 219; akademik uyum için 136, 671 ve 185; genel üniversiteye uyum için 128, 714 ve 150 kişilik gruplar elde edilmiştir. Tüm analizler üniversiteye uyum düzeylerine göre belirlenen bu gruplar üzerinde gerçekleştirilmiştir. 


\section{Bulgular}

\section{Üniversiteye uyumun cinsiyete dayalı farklılaşmasına ilişkin bulgular}

Öncelikle verilerin dağılımları incelenmiş normal dağılım göstermedikleri anlaşılmıştır. Bu sebeple üniversiteye uyum puanlarının cinsiyete göre farklılaşmasının belirlenmesi amacıyla parametrik olmayan Mann Whitney-U testi gerçekleştirilmiştir (Tablo 1).

Tablo 1. Farklı Uyum Düzeylerinin Cinsiyete Dayalı Farklılaşmasına İlişkin Mann Whitney-U Testi Sonuçlarn

\begin{tabular}{|c|c|c|c|c|c|c|c|c|}
\hline Boyut & Düzey & Cinsiyet & $\eta$ & $\bar{X}_{\text {sra }}$ & $\sum_{\text {srra }}$ & $\mathrm{U}$ & $\mathrm{Z}$ & $p$ \\
\hline \multirow{6}{*}{$\begin{array}{l}\text { Arkadaş } \\
\text { İlişkisinde } \\
\text { Uyum }\end{array}$} & \multirow{2}{*}{$\begin{array}{l}\text { Düşük } \\
\text { uyum }\end{array}$} & \multirow{2}{*}{$\begin{array}{l}\text { Erkek } \\
\mathrm{K}_{12}\end{array}$} & 54 & 62.82 & 3392.50 & \multirow{2}{*}{1907.50} & \multirow{2}{*}{-.71} & \multirow{2}{*}{.47} \\
\hline & & & 76 & 67.40 & 5122.50 & & & \\
\hline & \multirow{2}{*}{$\begin{array}{l}\text { Orta } \\
\text { uyum }\end{array}$} & \multirow{2}{*}{$\begin{array}{l}\text { Erkek } \\
\mathrm{K} 1 \mathrm{z}\end{array}$} & 260 & 313.28 & 81454.00 & \multirow{2}{*}{47524.00} & \multirow{2}{*}{-.93} & \multirow{2}{*}{.34} \\
\hline & & & 382 & 327.09 & 124949.00 & & & \\
\hline & \multirow{2}{*}{$\begin{array}{l}\text { Yüksek } \\
\text { uyum }\end{array}$} & \multirow{2}{*}{$\begin{array}{l}\text { Erkek } \\
\mathrm{K}_{1 \mathrm{z}} \\
\end{array}$} & 63 & 105.88 & 6670.50 & \multirow{2}{*}{4654.50} & \multirow{2}{*}{-.65} & \multirow{2}{*}{.51} \\
\hline & & & 156 & 111.66 & 17419.50 & & & \\
\hline \multirow{6}{*}{$\begin{array}{l}\text { Akademik } \\
\text { Uyum }\end{array}$} & \multirow{2}{*}{$\begin{array}{l}\text { Düşük } \\
\text { uyum }\end{array}$} & \multirow{2}{*}{$\begin{array}{l}\text { Erkek } \\
\mathrm{K} 1 \mathrm{z}\end{array}$} & 72 & 67.48 & 4858.50 & \multirow{2}{*}{2230.50} & \multirow{2}{*}{-.32} & \multirow{2}{*}{.74} \\
\hline & & & 64 & 69.65 & 4457.50 & & & \\
\hline & \multirow{2}{*}{$\begin{array}{l}\text { Orta } \\
\text { uyum } \\
\end{array}$} & \multirow{2}{*}{$\begin{array}{l}\text { Erkek } \\
\mathrm{K}_{12}\end{array}$} & 254 & 334.61 & 84991.00 & \multirow{2}{*}{52606.00} & \multirow{2}{*}{-.09} & \multirow{2}{*}{.92} \\
\hline & & & 416 & 336.04 & 139794.00 & & & \\
\hline & \multirow{2}{*}{$\begin{array}{l}\text { Yüksek } \\
\text { uyum }\end{array}$} & \multirow{2}{*}{$\begin{array}{l}\text { Erkek } \\
\text { Kız }\end{array}$} & 51 & 98.60 & 5028.50 & \multirow{2}{*}{3131.50} & \multirow{2}{*}{-.89} & \multirow{2}{*}{.37} \\
\hline & & & 134 & 90.87 & 12176.50 & & & \\
\hline \multirow{6}{*}{$\begin{array}{l}\text { Üniversiteye } \\
\text { Uyum }\end{array}$} & \multirow{2}{*}{$\begin{array}{l}\text { Düşük } \\
\text { uyum }\end{array}$} & \multirow{2}{*}{$\begin{array}{l}\text { Erkek } \\
\mathrm{K} 1 \mathrm{z}\end{array}$} & 63 & 65.24 & 4110.00 & 193800 & -38 & 70 \\
\hline & & & 64 & 62.78 & 4018.00 & 1930.00 & -.38 & .10 \\
\hline & Orta & Erkek & 272 & 332.71 & 90497.50 & 6685450 & -252 & 01 \\
\hline & uyum & $\mathrm{K} 1 \mathrm{z}$ & 442 & 372.75 & 164757.50 & 00834.50 & -2.02 & .01 \\
\hline & Yüksek & Erkek & 42 & 69.85 & 2933.50 & 203050 & -10 & 31 \\
\hline & uyum & $\mathrm{K} 1 \mathrm{z}$ & 108 & 77.70 & 8391.50 & 2000.00 & -1.00 & 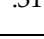 \\
\hline
\end{tabular}

Sonuçlar yalnızca üniversiteye genel uyum puanlarında orta uyum düzeyinde kızlar ve erkekler arasında anlamlı bir farklılık gözlendiğini göstermektedir [U $=66854.50, p<.01]$.

Ortaya çıkan anlamlı fark kaynağına bakıldığında, aradaki anlamlı farkın kızların uyuma ilişkin sıra ortalamalarının ( $\left.\bar{X}_{\text {sıra }}=372.75\right)$ erkeklerin sıra ortalamalarından $\left(\bar{X}_{\text {sra }}=332.71\right)$ yüksek olmasından kaynaklandığı anlaşılmaktadır. 


\section{Üniversiteye uyumun fakülteye dayalı farklılaşmasına ilişkin bulgular}

Öğrenim görülen fakültenin üniversiteye uyumda farklılaşmasını belirlenmesi amacıyla Kruskal Wallis testi gerçekleştirilmiştir. Analizler arkadaş ilişkisinde uyum, akademik uyum ve üniversiteye genel uyum olmak üzere üç ayrı düzeyde de analiz edilmiştir. Analiz sonucunda arkadaş ilişkisinde uyum alt boyutunun düşük $\left(\chi^{2}(5)=11.22 ; p<.05\right)$, orta $\left(\chi^{2}{ }_{(5)}=13.06 ; p<.05\right)$ ve yüksek $\left(\chi^{2}(5)=11.72 ; p<.05\right)$ olmak üzere üç düzeyde de anlamlı farklılaşma gösterdiği belirlenmiş̧ir (Tablo 2).

Her üç uyum düzeyinde ortaya çıan anlamlı farklılığın kaynaklarının belirlenmesi amacıyla ikili Mann Whitney U testleri gerçekleştirilmiştir. Arkadaş ilişkisinde düşük uyum düzeyindeki farklılaşmanın kaynağının fen-edebiyat fakültesi öğrencilerinin sıra ortalamalarının ( $\left.\bar{X}_{\text {srra }}=31.80\right)$ tıp fakültesi öğrencilerinin sıra ortalamalarından $\left(\bar{X}_{\text {srra }}=23.44\right)$; mimarlık-mühendislik fakültesi öğrencilerinin sıra ortalamalarının $\left(\bar{X}_{\text {srra }}=23.64\right)$ tıp fakültesi öğrencilerinin sıra ortalamalarından ( $\left.\bar{X}_{\text {srra }}=16.24\right)$; eğitim fakültesi öğrencilerinin sıra ortalamalarının ( $\left.\bar{X}_{\text {srra }}=26.97\right)$ tıp fakültesi öğrencilerinin sıra ortalamalarından ( $\left.\bar{X}_{\text {srra }}=16.62\right)$ ve eğitim fakültesi öğrencilerinin sıra ortalamalarının ( $\left.\bar{X}_{\text {sra }}=24.17\right)$ ilahiyat fakültesi öğrencilerinin sıra ortalamalarından ( $\bar{X}_{\text {sra }}=16.46$ ) yüksek olmasından kaynaklandığı belirlenmiştir.

Arkadaş ilişkisinde orta uyum düzeyine sahip öğrenciler arasındaki farkın iktisadi ve idari bilimler fakültesi öğrencilerinin sıra ortalamalarının ( $\bar{X}$ srra $=122.71)$ tıp fakültesi öğrencilerinin sıra ortalamalarından $\left(\bar{X}_{\text {srra }}=98.52\right)$; ilahiyat fakültesi öğrencilerinin sıra ortalamalarının ( $\left.\bar{X}_{\text {sra }}=123.42\right)$, tıp fakültesi öğrencilerinin sıra ortalamalarından $\left(\bar{X}_{\text {srra }}=99.62\right)$; eğitim fakültesi öğrencilerinin sıra ortalamalarının ( $\left.\bar{X}_{\text {sra }}=119.19\right)$ tıp fakültesi öğrencilerinin sıra ortalamalarından ( $\bar{X}_{\text {srra }}=96.71$ ) yüksek olmasından kaynaklandığı belirlenmiştir. 
Tablo 2. Arkadaş İlişkisinde Uyum Düzeylerinin Fakülte Değişkenine Göre Farklılaşmasına İlişkin Kruskal Wallis Testi Sonuçları

\begin{tabular}{|c|c|c|c|c|c|c|c|}
\hline Boyut & Düzey & Grup & $\eta$ & $\bar{X}_{\text {sra }}$ & $\mathrm{Sd}$ & $\chi^{2}$ & $p$ \\
\hline \multirow{18}{*}{$\begin{array}{l}\text { Arkadaş } \\
\text { İlişkisinde } \\
\text { Uyum }\end{array}$} & \multirow{6}{*}{ Düşük Uyum } & Fen-edebiyat & 30 & 71.30 & \multirow{6}{*}{5} & \multirow{6}{*}{11.22} & \multirow{6}{*}{.04} \\
\hline & & Tip & 25 & 51.44 & & & \\
\hline & & Mim-mühendislik & 11 & 78.05 & & & \\
\hline & & İktisat-İşletme & 27 & 62.89 & & & \\
\hline & & İlahiyat & 23 & 59.74 & & & \\
\hline & & Eğitim & 15 & 86.03 & & & \\
\hline & \multirow{6}{*}{ Orta Uyum } & Fen-edebiyat & 103 & 304.12 & \multirow{6}{*}{5} & \multirow{6}{*}{13.06} & \multirow{6}{*}{.02} \\
\hline & & Tip & 107 & 273.09 & & & \\
\hline & & Mim.-mühendislik & 94 & 318.77 & & & \\
\hline & & İktisat-İşletme & 114 & 345.50 & & & \\
\hline & & İlahiyat & 116 & 343.09 & & & \\
\hline & & Eğitim & 108 & 339.88 & & & \\
\hline & \multirow{6}{*}{ Yüksek Uyum } & Fen-edebiyat & 37 & 128.20 & \multirow{6}{*}{5} & \multirow{6}{*}{11.72} & \multirow{6}{*}{.03} \\
\hline & & Tip & 22 & 82.61 & & & \\
\hline & & Mim.-mühendislik & 19 & 105.68 & & & \\
\hline & & İktisat-İşletme & 37 & 94.45 & & & \\
\hline & & İlahiyat & 54 & 115.91 & & & \\
\hline & & Eğitim & 50 & 115.35 & & & \\
\hline
\end{tabular}

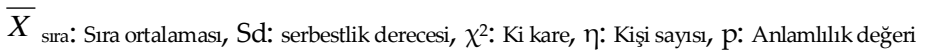

Arkadaş ilişkisinde yüksek uyum düzeyine sahip öğrenciler arasındaki farkın fen-edebiyat fakültesi öğrencilerinin sıra ortalamalarının ( $\left.\bar{X}_{\text {sra }}=34.46\right)$ tıp fakültesi öğrencilerinin sıra ortalamalarından ( $\left.\bar{X}_{\text {sıra }}=22.50\right)$; fen-edebiyat fakültesi öğrencilerinin sıra ortalamalarının ( $\left.\bar{X}_{\text {sra }}=43.18\right)$ iktisadi ve idari bilimler fakültesi öğrencilerinin sıra ortalamalarından $\left(\bar{X}_{\text {sra }}=31.82\right)$; ilahiyat fakültesi öğrencilerinin sıra ortalamalarının $\left(X_{\text {sıra }}=41.74\right)$ tıp fakültesi öğrencilerinin sıra ortalamalarından ( $\left.\bar{X}_{\text {sıra }}=30.55\right)$; eğitim fakültesi öğrencilerinin sıra ortalamalarının ( $\bar{X}_{\text {sıra }}=39.78$ ) tıp fakültesi öğrencilerinin sıra ortalamalarından ( $\bar{X}_{\text {srra }}=29.05$ ) yüksek kaynaklandığ 1 tespit edilmiştir.

Akademik uyum bağlamında gerçekleştirilen analizlerde farklı fakültelerde öğrenim görmekte olan öğrenciler arasında orta düzeyli akademik uyuma sahip öğrenciler arasında anlamlı farklar meydana geldiği belirlenmiştir $\left(\chi^{2}(5)=12.03 ; p<.05\right)$. Sonuçlar Tablo 3'te özetlenmiştir. 
Tablo 3. Akademik Uyum Düzeylerinin Fakülte Değişkenine Göre Farklılaşmasına İlişkin Kruskal Wallis Testi Sonuçlarn

\begin{tabular}{|c|c|c|c|c|c|c|c|}
\hline Boyut & Düzey & Grup & $\eta$ & $\bar{X}_{\text {sra }}$ & $\mathrm{Sd}$ & $\chi^{2}$ & $p$ \\
\hline \multirow{18}{*}{$\begin{array}{l}\text { Akademik } \\
\text { Uyum }\end{array}$} & \multirow{6}{*}{$\begin{array}{l}\text { Düşük } \\
\text { Uyum }\end{array}$} & Fen-edebiyat & 28 & 73.34 & \multirow{6}{*}{5} & \multirow{6}{*}{7.09} & \multirow{6}{*}{.21} \\
\hline & & Tip & 21 & 71.93 & & & \\
\hline & & Mim.-mühendislik & 17 & 57.50 & & & \\
\hline & & İktisat-İşletme & 22 & 80.16 & & & \\
\hline & & İlahiyat & 20 & 72.15 & & & \\
\hline & & Eğitim & 28 & 56.00 & & & \\
\hline & \multirow{6}{*}{$\begin{array}{l}\text { Orta } \\
\text { Uyum }\end{array}$} & Fen-edebiyat & 121 & 299.36 & \multirow{6}{*}{5} & \multirow{6}{*}{12.03} & \multirow{6}{*}{.03} \\
\hline & & Tip & 102 & 336.22 & & & \\
\hline & & Mim.-mühendislik & 98 & 313.23 & & & \\
\hline & & İktisat-İşletme & 129 & 332.25 & & & \\
\hline & & İlahiyat & 123 & 371.20 & & & \\
\hline & & Eğitim & 98 & 364.53 & & & \\
\hline & \multirow{6}{*}{$\begin{array}{l}\text { Yüksek } \\
\text { Uyum }\end{array}$} & Fen-edebiyat & 21 & 98.86 & \multirow{6}{*}{5} & \multirow{6}{*}{6.51} & \multirow{6}{*}{.25} \\
\hline & & Tip & 31 & 80.05 & & & \\
\hline & & Mim.-mühendislik & 9 & 107.28 & & & \\
\hline & & İktisat-İşletme & 27 & 77.93 & & & \\
\hline & & İlahiyat & 50 & 95.65 & & & \\
\hline & & Eğitim & 47 & 102.03 & & & \\
\hline
\end{tabular}

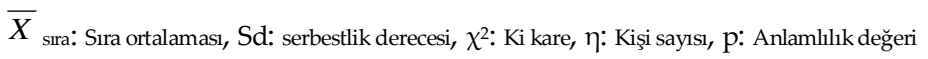

Orta düzeyli akademik uyumda ortaya çıkan farkın ilahiyat fakültesi öğrencilerinin sıra ortalamalarının ( $\left.\bar{X}_{\text {srra }}=134.60\right)$ fen-edebiyat fakültesi öğrencilerinin sıra ortalamalarından ( $\left.\bar{X}_{\text {srra }}=110.20\right)$; eğitim fakültesi öğrencilerinin sıra ortalamalarının ( $\left.\bar{X}_{\text {srra }}=121.58\right)$ fen-edebiyat fakültesi öğrencilerinin sıra ortalamalarından ( $\bar{X}_{\text {srra }}=100.62$ ); ilahiyat fakültesi öğrencilerinin sıra ortalamalarının ( $\bar{X}_{\text {srra }}=119.62$ ) mimarlık-mühendislik fakültesi öğrencilerinin sıra ortalamalarından ( $\bar{X}_{\text {sira }=100.18)}$ yüksek olmasından kaynaklandığı tespit edilmiştir.

Üniversiteye genel uyuma bakıldığında orta düzeyde üniversiteye uyum gösteren öğrencilerin fakültelere göre farklılaştığ gözlenmiştir $\left(\chi^{2}(5)=17.89\right.$; $p<.05)$. Kruskal Wallis testinin sonuçları Tablo 4 'te özetlenmiştir. 
Tablo 4. Üniversiteye Uyum Düzeylerinin Fakülte Değişkenine Göre Farklılaşmasına İlişkin Kruskal Wallis Testi Sonuçları

\begin{tabular}{|c|c|c|c|c|c|c|c|}
\hline Boyut & Düzey & Grup & $\eta$ & $\bar{X}_{\text {sra }}$ & Sd & $\chi^{2}$ & $p$ \\
\hline \multirow{18}{*}{$\begin{array}{l}\text { Üniversiteye } \\
\text { Uyum }\end{array}$} & \multirow{6}{*}{ Düşük Uyum } & Fen-edebiyat & 29 & 66.88 & & \multirow{6}{*}{2.60} & \multirow{6}{*}{.76} \\
\hline & & Tip & 27 & 57.85 & & & \\
\hline & & Mim.-mühendislik & 14 & 60.89 & & & \\
\hline & & İktisat-İşletme & 21 & 72.90 & & & \\
\hline & & İlahiyat & 19 & 60.55 & & & \\
\hline & & Eğitim & 18 & 67.81 & & & \\
\hline & \multirow{6}{*}{$\begin{array}{l}\text { Orta } \\
\text { Uyum }\end{array}$} & Fen-edebiyat & 117 & 307.23 & & \multirow{6}{*}{17.89} & \multirow{6}{*}{.00} \\
\hline & & Tip & 109 & 372.22 & & & \\
\hline & & Mim.-mühendislik & 103 & 328.34 & & & \\
\hline & & İktisat-İşletme & 136 & 354.23 & & & \\
\hline & & İlahiyat & 134 & 408.00 & & & \\
\hline & & Eğitim & 115 & 365.83 & & & \\
\hline & \multirow{6}{*}{ Yüksek Uyum } & Fen-edebiyat & 24 & 71.50 & & \multirow{6}{*}{9.50} & \multirow{6}{*}{.09} \\
\hline & & Tip & 18 & 50.06 & & & \\
\hline & & Mim.-mühendislik & 7 & 96.21 & 5 & & \\
\hline & & İktisat-İşletme & 21 & 73.79 & J & & \\
\hline & & İlahiyat & 40 & 80.18 & & & \\
\hline & & Eğitim & 40 & 81.95 & & & \\
\hline
\end{tabular}

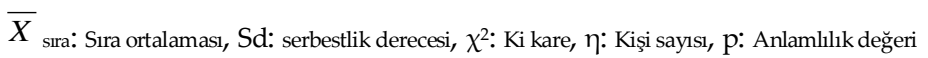

Orta düzeyde üniversiteye uyum sağlayan öğrenciler arasındaki farkın tıp fakültesi öğrencilerinin uyum puanı sıra ortalamalarının ( $\bar{X}$ sira=124.11) fenedebiyat fakültesi öğrencilerinin sıra ortalamalarından ( $\bar{X}$ sıra= 103.62); iktisadi ve idari bilimler fakültesi öğrencilerinin sıra ortalamaları ( $\bar{X}_{\text {sra }}=136.21$ ) fen-edebiyat fakültesi öğrencilerinin sıra ortalamalarından ( $\left.\bar{X}_{\text {srra }}=116.29\right)$; ilahiyat fakültesi öğrencilerinin sıra ortalamalarının $\left(\bar{X}_{\text {srra }}=140.87\right)$ fen-edebiyat fakültesi öğrencilerinin sıra ortalamalarından $\left(\bar{X}_{\text {sıra }}=108.97\right)$; ilahiyat fakültesi öğrencilerinin sıra ortalamalarının $\left(\bar{X}_{\text {sra }}=130.97\right)$ mimarlık-mühendislik fakültesi öğrencilerinin sıra ortalamalarından $\quad\left(\bar{X}_{\text {sıra }}=103.42\right)$; ilahiyat fakültesi öğrencilerinin sıra ortalamalarının ( $\left.\bar{X}_{\text {sra }} 146.41\right)$ iktisadi ve idari bilimler fakültesi öğrencilerinin sıra ortalamalarından $\left(\bar{X}_{\text {sira }}=124.75\right)$ fazla olmasından kaynaklandığı görülmektedir. 


\section{Üniversiteye uyumun sını düzeyine dayalı farklılaşmasına ilişkin bulgular}

Farklı üniversiteye uyum düzeylerinin fakülte değişkenine göre farklılaşıp farklılaşmadığını belirlemek amacıyla bir dizi Kruskal Wallis testi gerçekleştirilmiştir. Analizler arkadaş ilişkisinde uyum, akademik uyum ve toplam uyum puanları üzerinden gerçekleştirilmiştir. İlk olarak arkadaş ilişkisinde uyum boyutunda analiz yapılmıştır. Düşük ve yüksek düzeyde arkadaş ilişkisinde uyuma sahip öğrencilerde bir farklılaşma gözlenmezken orta düzeyde arkadaş ilişkisinde uyuma sahip olan grubun sinıf düzeyine göre anlamlı bir farklılık gösterdiği belirlenmiştir $\left(\chi^{2}(3)=11.11 ; p<.05\right)$. Sonuçlar Tablo 5 'te özetlenmiştir.

Tablo 5. Üniversite Öğrencilerinin Arkadaş İlişkisinde Uyum Puanlarnnın Sinıf Değişkenine Göre Farklılaşmalarnı Gösteren Kruskal Wallis Sonuçları

\begin{tabular}{|c|c|c|c|c|c|c|c|}
\hline Boyut & Düzey & Grup & $\eta$ & $\bar{X}_{\text {sra }}$ & $\mathrm{Sd}$ & $\chi^{2}$ & $p$ \\
\hline \multirow{12}{*}{$\begin{array}{l}\text { Arkadaş } \\
\text { ilişkisinde } \\
\text { Uyum }\end{array}$} & \multirow{4}{*}{$\begin{array}{l}\text { Düşük } \\
\text { Uyum }\end{array}$} & 1.sinif & 29 & 62.26 & \multirow{4}{*}{-3} & \multirow{4}{*}{.47} & \multirow{4}{*}{.92} \\
\hline & & 2.sinif & 45 & 66.82 & & & \\
\hline & & 3.sinif & 33 & 68.39 & & & \\
\hline & & 4.sinif & 24 & 65.69 & & & \\
\hline & \multirow{4}{*}{$\begin{array}{l}\text { Orta } \\
\text { Uyum }\end{array}$} & 1. sinif & 154 & 322.88 & \multirow{4}{*}{-3} & \multirow{4}{*}{11.11} & \multirow{4}{*}{.01} \\
\hline & & 2.sinif & 196 & 288.30 & & & \\
\hline & & 3.sinif & 171 & 350.17 & & & \\
\hline & & 4.sinif & 121 & 333.02 & & & \\
\hline & \multirow{4}{*}{$\begin{array}{l}\text { Yüksek } \\
\text { Uyum }\end{array}$} & 1.sinif & 40 & 119.73 & \multirow{4}{*}{-3} & \multirow{4}{*}{1.51} & \multirow{4}{*}{.67} \\
\hline & & 2.sinif & 65 & 107.84 & & & \\
\hline & & 3.sinif & 58 & 105.37 & & & \\
\hline & & $4 . \sin 1 \mathrm{f}$ & 56 & 110.36 & & & \\
\hline
\end{tabular}

Ortaya çıkan anlamlı farkın kaynağının belirlenmesi amacıyla gerçekleştirilen ikili Mann Whitney U testleri sonucunda orta düzeyde arkadaş ilişkisinde uyum gösteren öğrenciler arasındaki farkın üçüncü sınıf öğrencilerinin sira ortalamalarının ( $\left.\bar{X}_{\text {srra }}=203.05\right)$ ikinci sınıf öğrencilerinin sıra ortalamalarından $\left(\bar{X}_{\text {srra }}=167.38\right)$; dördüncü sınıf öğrencilerinin sıra ortalamalarının $(\bar{X}$ srra $=172.74)$ ikinci sınıf öğrencilerinin sıra ortalamalarından $\left(\bar{X}_{\text {sra }}=150.52\right)$ fazla olmasından kaynaklandığı belirlenmiştir.

Akademik uyum boyutuyla gerçekleştirilen analizler sonucunda düşük, orta ve yüksek olmak üzere her üç düzeyde anlamlı bir farklılık oluşmadığı gözlenmiştir. Sonuçlar Tablo 6'da özetlenmiştir. 
Tablo 6. Üniversite Öğrencilerinin Akademik Uyum Puanlarının Sınf Değişkenine Göre Farklılaşmaların Gösteren Kruskal Wallis Sonuçları

\begin{tabular}{|c|c|c|c|c|c|c|c|}
\hline Boyut & Düzey & Grup & $\eta$ & $\bar{X}_{\text {sra }}$ & $\mathrm{Sd}$ & $x^{2}$ & $p$ \\
\hline \multirow{12}{*}{$\begin{array}{l}\text { Akademik } \\
\text { Uyum }\end{array}$} & & 1.smif & 39 & 67.53 & & \multirow{4}{*}{.08} & \multirow{4}{*}{.99} \\
\hline & Düşük & 2.sinif & 47 & 68.48 & & & \\
\hline & \multirow[t]{2}{*}{ Uyum } & $3 . \operatorname{sinff}$ & 26 & 70.31 & & & \\
\hline & & 4.sinif & 24 & 68.17 & & & \\
\hline & \multirow{4}{*}{$\begin{array}{l}\text { Orta } \\
\text { Uyum }\end{array}$} & 1. sinif & 147 & 351.75 & & \multirow{4}{*}{1.56} & \multirow{4}{*}{.66} \\
\hline & & 2.sinif & 203 & 336.12 & & & \\
\hline & & 3. sinuf & 179 & 325.29 & & & \\
\hline & & 4.sinif & 142 & 333.02 & & & \\
\hline & \multirow{4}{*}{$\begin{array}{l}\text { Yüksek } \\
\text { Uyum }\end{array}$} & 1. sinff & 37 & 81.84 & & \multirow{4}{*}{3.77} & \multirow{4}{*}{.28} \\
\hline & & 2.sinif & 56 & 100.73 & & & \\
\hline & & 3.sinif & 57 & 88.68 & & & \\
\hline & & $4 . \operatorname{sinff}$ & 35 & 99.46 & & & \\
\hline
\end{tabular}

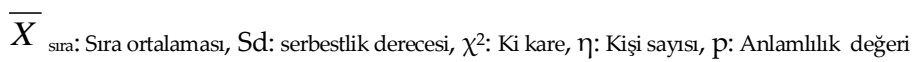

Toplam uyum puanlarına göre gerçekleştirilen Kruskal Wallis testi ile akademik uyuma benzer şekilde düşük, orta ve yüksek üniversiteye uyum düzeylerinde de anlamlı bir farkın ortaya çıkmadığı gözlenmiştir. Sonuçlar Tablo 7'de özetlenmiştir.

Tablo 7. Üniversite Öğrencilerinin Toplam Uyum Puanlarnın Sınıf Değişkenine Göre Farklılaşmaların Gösteren Kruskal Wallis Sonuçları

\begin{tabular}{|c|c|c|c|c|c|c|c|}
\hline Boyut & Düzey & Grup & $\eta$ & $X_{\text {sra }}$ & S.d & $\chi^{2}$ & $p$ \\
\hline \multirow{12}{*}{$\begin{array}{l}\text { Üniversiteye } \\
\text { Uyum }\end{array}$} & \multirow{4}{*}{$\begin{array}{l}\text { Düşük } \\
\text { Uyum }\end{array}$} & 1.sinif & 36 & 64.08 & \multirow{4}{*}{-3} & \multirow{4}{*}{.74} & \multirow{4}{*}{.86} \\
\hline & & 2.sinif & 39 & 65.77 & & & \\
\hline & & 3.sinif & 30 & 60.20 & & & \\
\hline & & 4.sinif & 23 & 68.61 & & & \\
\hline & \multirow{4}{*}{$\begin{array}{l}\text { Orta } \\
\text { Uyum }\end{array}$} & 1.sinif & 160 & 370.83 & \multirow{4}{*}{-3} & \multirow{4}{*}{5.24} & \multirow{4}{*}{.15} \\
\hline & & 2.sinif & 224 & 331.63 & & & \\
\hline & & 3.sinif & 182 & 365.72 & & & \\
\hline & & 4.sinif & 148 & 372.13 & & & \\
\hline & \multirow{4}{*}{$\begin{array}{l}\text { Yüksek } \\
\text { Uyum }\end{array}$} & $\underline{1 . s i n i f}$ & 27 & 68.87 & & \multirow{4}{*}{4.17} & \multirow{4}{*}{.24} \\
\hline & & 2.sinif & 43 & 77.60 & & & \\
\hline & & 3.sinif & 50 & 69.75 & & & \\
\hline & & 4.sinif & 30 & 88.03 & & & \\
\hline
\end{tabular}

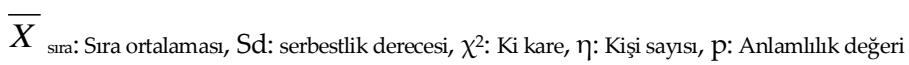




\section{Tartışma}

Bu çalışmada cinsiyet, öğrenim görülen fakülte ve sınıf düzeyi değişkenlerinin farklı düzeylerde üniversiteye uyum sağlamış olan üniversite öğrencilerinde farklılaşmaya sebep olup olmayacağı araştırılmıştır. Bu doğrultuda incelenen değişkenler sıralı olarak ele alınmış ve başlıklar halinde tartışılmıştır.

\section{Farklı Üniversiteye Uyum Düzeylerinin, Cinsiyete Göre Farklılaşmasına İlişkin Sonuç Ve Tartışma}

Araştırmada arkadaş ilişkisinde uyum ve akademik uyum faktörlerine ait uyum düzeylerinin hiçbirinde anlamlı bir farklılık olmadığı gözlenmiştir. Üniversiteye genel uyum bağlamında gerçekleştirilen analizde düşük ve yüksek uyum düzeyindeki öğrencilerde cinsiyet faktörünün herhangi bir farklılığa neden olmadığı, buna karşın orta düzey uyuma sahip öğrencilerde kızların lehine anlamlı bir farkın olduğu belirlenmiştir. Bu sonuca göre üniversiteye orta düzeyde uyum sağlama konusunda kızların lehine bir durum olduğu, bir başka ifadeyle kız öğrencilerin orta düzeyde üniversiteye uyum sağlama konusunda avantaj sağladıkları söylenebilir.

Literatürde kız ve erkeklerin üniversiteye uyum düzeylerine ilişkin farklı sonuçlar bulunmaktadır. Bu sonuçlar arasında erkeklerin üniversite ortamina daha uyumlu olduğunu gösterenler olduğu gibi (Altunay, 2010; Öztemel, 2010; Şahin ve Tunçel, 2008) cinsiyetin bir farklılık yaratmadığını (Aladağ Bayrak ve Bülbül, 2013; Alver, 1998; Darlow, Norvilitis ve Schuetze, 2017) veya belirli alanlarda kızların daha yüksek düzeyde uyum gösterdiğini ortaya koyan bulgular da (Gökkaya, 2016, s.60; Hum ve Falci, 2016, s.1; Sánchez, Colón ve Esparza, 2005, s.624) mevcuttur. Literatürde kızların daha yüksek umut düzeyine (Şahin, 2009) ve yaşam doyumuna (Dost, 2007) sahip olduklarına ilişkin bulgular, kız öğrencilerin zorluklarla mücadele güçlerini kullanarak iyi bir uyum sağlayabiliyor olmalarının bir açıklaması olabilir. Literatürde kızların erkeklerden daha fazla yardım arama davranışı sergiledikleri (Çebi, 2009; Yalım, 2007) ve erkeklere oranla ailelerinden daha az reddedilmeye maruz kaldıkları bildirilmiştir (Keskiner, 2012). Ayrıca sosyal destek alanında yürütülmüş araştırmalarda kızların erkeklerden daha yüksek düzeyde sosyal desteğe sahip olduğu (Orman, 2016; Sayar, 2006; Sever, 2015) ve kızların bu sosyal destekten erkeklere oranla daha fazla yarar sağladıkları be- 
lirlenmiştir (Milner, Krnjacki ve LaMontagne, 2016). Kızların gerek arkadaştan gerekse aileden elde edilen sosyal desteği kullanma oranlarının erkeklerden yüksek olduğuna ilişkin veriler de bulunmaktadır (Kartal ve Çetinkaya, 2009). Bu durum kızların sosyal destek kaynaklarını çeşitlendirdiği ve erkeklerden daha verimli kullandığı bulgusuyla (Diaz ve Bui, 2017) örtüşmektedir. Cheung ve Sim (2017) kızların mesleki konularda ebeveynlerden, duygusal konularda arkadaşlarından destek aldıklarını ve bu sayede uygun destek türüne yönelerek sorunların çözümüne işlevsel yaklaştıklarını tespit etmiştir. Bu noktada kızların sağlıklı sosyal çevre edinerek sosyal uyumu, arkadaşlarıyla birlikte çalışmalar yürüterek akademik uyumu ve sorunlarını çevresiyle paylaşarak da genel üniversiteye uyumu başarılı bir şekilde gerçekleştirdikleri düşünülebilir.

\section{Farklı Üniversiteye Uyum Düzeylerinin, Öğrenim Görülen Fakülteye Göre Farklılaşmasına İlişkin Sonuç Ve Tartışma}

Bu çalışmada farklı uyum düzeylerindeki üniversite öğrencilerinin arkadaş ilişkisinde uyum, akademik uyum ve genel uyum puanlarının öğrenim gördükleri fakültelere göre farklılaşıp farklılaşmadığı sınanmıştır.

Arkadaşlarıyla uyum düzeyi düşük olan öğrenciler arasında eğitim, fenedebiyat ve mimarlık-mühendislik fakültesi öğrencilerinin avantajlı olduğu görülmektedir. Ĕ̆itim fakültesi öğrencilerinin umutsuzluk düzeylerinin az (Şahin, 2009) ve uyum sağlamaya yatkın olmaları (Erdoğan, Şanlı ve Şimşek Bekir, 2005) bu bulguyu desteklemektedir. Fen-edebiyat ve mimarlık-mühendislik fakültelerindeki durum ise bu iki fakültedeki öğrencilerin sosyal ilişkilerdeki tolerans düzeylerinin yüksek olmasıyla alakalı olabilir (Sönmez, 2019). İktisat, ilahiyat ve eğitim fakültesi öğrencilerinin orta düzeydeki arkadaş uyumunda avantajlı olduğuna ilişkin bulgu ise bu bireylerin dışadönük (McCrae ve Costa, 1985) veya sosyal (Siyez, n.d.; Yeşilyaprak, n.d.) kişilik özelliklerine sahip olmalarıyla alakalı olabilir. Gülücü'nün (2017), sosyal kişilik tipi ile muhasebe-finansman bölümü arasında anlamlı bir ilişki olduğunu bulgulaması bu görüşü desteklemektedir. İlahiyat fakültesi öğrencileri açısından ise hoşgörü düzeylerinin yüksek olması (Arıcı ve Tokur, 2017) bu durumun bir açılaması olabilir. En yüksek düzeyde arkadaş ilişkisi uyumu olan grupta Fen ve Edebiyat Fakültesi öğrencilerinin avantajlı olmasının sebebi ise atanma ve iş bulma konusunda yaşadıkları yoğun kaygıdan (Fırıncı Orman, 
2016; Şanlı Kula ve Saraç, 2017) kurtulmak için sosyal ilişkilerde sağlayacakları doyum aracı olarak kullanmaları olabilir.

Akademik uyum becerisine göre yapılan analizlerde yalnızca orta uyum düzeyinde anlamlı bir farklılığın ortaya çıtığı belirlenmiştir. Orta düzeyli akademik uyumda ilahiyat, eğitim ve tıp fakülteleri en avantajlı gruplardır. Eğitim fakültesi öğrencilerinin akademik uyum düzeylerinin yüksek olması genel uyum becerilerinden elde ettikleri motivasyonla akademik başarılar elde etmeleri olabilir (Mercan ve Yıldız, 2011). İlahiyat fakültesi öğrencilerinin akademik uyumlarının yüksek olma sebebi ise bu öğrencilerin okuldan önce aileleri tarafından dini bilgiler konusunda eğitilmiş olmaları olabilir (Keskin, 2003). Tıp fakültesi öğrencilerinin de çoğunlukla fen lisesi çıkışlı olmaları (Türk, 2018) ve en yüksek yerleşme puanıla üniversiteye yerleşen kesimde bulunmaları (Alp, 2019) bu durumun bir açıklaması olabilir.

Üniversiteye genel uyum düzeylerine göre yapılan analizlerde İlahiyat Fakültesinin en yüksek düzeyde uyuma sahip öğrencilere sahip olduğu, bunu Trp ve Eğitim Fakültesi öğrencilerinin izlediği görülmektedir. Fen-Edebiyat ile Mimarlık-Mühendislik Fakülteleri öğrencilerinin ise en düşük düzeyde uyuma sahip olduğu belirlenmiştir. İlahiyat fakültesi öğrencilerinin uyum becerilerinin yüksek olma sebebi atanma oranlarının yüksek olması (MEB, 2017), iş garantisi algılarının yüksek olması (Nazıroğlu, Acuner ve Birinci, 2017) ve dolayısıyla yakın hedeflere uzak hedeflere oranla daha iyi motive olmaları (Lucariello ve diğ., 2016; Stock ve Cervone, 1990) olabilir. Ayrıca dini faaliyetlere katılımın bireyin öz-saygısını (Sherkat ve Reed, 1992), maneviyatınsa zorluklarla mücadele becerisini artırması (Glenn, 2014) bir diğer etken olabilir. Iş garantisinin bulunması tıpkı Ilahiyat Fakültesi gibi Tıp fakültesi öğrencilerinin uyum becerilerinin artışında da (Alper ve Özdemir, 2004; Köksal, Vehid, Tunçkale, Sipahioğlu ve Özbal, 2014; Yarış, Topbaş, Çan ve Özoran, 2001) etkili olmuş olabilir. Bu fakültelere giden öğrencilerin yurt d1şında olduğu gibi (Hyppölä ve diğ., 1998) Türkiye'de de en başarılı öğrencilerden seçilmesi (Genç, Kaya ve Genç, 2007) akademik açıdan zaten başarılı olan bu topluluğun birbirine uyum sağlama açısından avantaj yarattı̆̆ını düşündürmektedir. Bununla birlikte benzer kişilik tipinde olmaları (Vedel, 2016), büyük ölçüde yüksek sosyo-ekonomik gelir düzeyinden gelmeleri (Sadıkoğlu ve diğ., 2003) de uyum sağlamalarını kolaylaştırmış olabilir. Uyum becerisi yüksek grupların aksine bu becerileri düşük olan Mimarlık-Mühendislik ile Fen-Edebiyat fakültesi öğrencilerinin atanma durumlarının daha 
kötü olması (Ersan, 2017; Fırıncı Orman, 2016; İlhami ve Oral, 2011) üniversiteye uyum düzeyini düşürmüş olabilir. Ayrıca Fen ve Edebiyat fakültesi öğrencilerinin depresyona karşı eğilimlerinin yüksek olması (Özdel, Bostancı, Özdel ve Oğuzhanoğlu'nun, 2002), geleceğe yönelik kaygılar barındırmaları (Şanlı Kula ve Saraç, 2017) uyum sorunu yaşamalarına sebep olmuş olabilir. Bununla birlikte öğrencilerin barınma (Filiz ve Çemrek, 2006) ve fakülte içerisinde tercih edilen bölümlerin farklılığı gibi bireylerin mutluluk düzeylerine etki eden faktörler de (Sevüktekin, Nargeleçekenler ve Çetin, 2012) uyum becerisi üzerinde etkili olmuş olabilir.

\section{Farklı Üniversiteye Uyum Düzeylerinin, Sını Düzeyine Göre Farklılaşmasına İlişkin Sonuç Ve Tartışma}

Çalışmanın son bölümünde düşük, orta ve yüksek uyum düzeyindeki üniversite öğrencilerinin arkadaş ilişkisinde uyum, akademik uyum ve toplam uyum puanlarının öğrenim gördükleri sınıf düzeyine göre farklılaşıp farkl1laşmadığı sınanmıştır. Sonuçlar akademik ve genel uyum puanlarında her üç uyum düzeyinde de anlamlı bir farklılaşmanın olmadığını göstermiştir. Bununla birlikte arkadaş ilişkisinde uyum boyutunda orta düzey uyuma sahip öğrenciler arasında anlamlı bir farklılaşmanın olduğu belirlenmiştir. Ayrıca elde edilen bulgular öğrencilerin ilk yıl yüksek olan arkadaş ilişkisinde uyum puanlarının ikinci yıl keskin bir düşüş gösterdiğine, üçüncü yıl aynı şekilde keskin bir yükselişe geçtiğine ve son yıl dengeli bir noktada sabitlendiğine işaret etmektedir. Bu sonuçlara göre üniversiteye gelen öğrencilerin ilk yıl henüz arkadaş çevresini tam olarak belirlememiş olmalarına bağlı olarak uyumlu olduklarına ilişkin bir ön algılarının olduğu, ikinci yıl farklı çevrelerden gelen çok sayıda arkadaşla etkileşime girince anlaşmazlıkların baş gösterdiği ve uyum düzeyinde ani bir düşüş sergilediği düşünülebilir. Üçüncü yıl ilişkisel krizlerin yavaş yavaş çözülmeye başlamasıyla uyum düzeyinin yükselişe geçtiği, dördüncü yılda ise arkadaş çevresinin belirlenmesi ve kabul edilen arkadaşlarla iletişim halinde kalındığı, kriz yaşanan arkadaşlarla iletişimin azaltılmasıyla uyum düzeyinin en uygun seviyede dengelendiği söylenebilir.

Üniversiteye başlanan ilk yıl birçok belirsizliğin olması dolayısıyla öğrenciler üzerinde genelde bir stres bulunsa da bu stres, dönemin sonunda büyük ölçüde azalmaktadır (Olmstead ve dĭğ., 2012). Gerek evde gerek yurtta kalan 
öğrenciler aileden ayrı bir ortamda kalmanın bilgi paylaşımı, olgunlaşma, ölçülü harcamayı öğrenme gibi konularda kendilerini daha öz-güvenli hissettirdiğini ifade etmektedir (Arlı, 2013). Dolayısıyla zaman geçtikçe öğrencilerin birbiriyle olan samimiyet düzeyleri doğal olarak artıs göstermekte ve birbirleriyle olan paylaşımları artmaktadır. Bu noktada, artan etkileşimle birlikte anlaşmazlıklar da baş gösteriyor olabilir. Arı (1989) birinci sınıf öğrencileri ile dördüncü sınıf öğrencilerinin üniversiteye uyum durumlarını incelediği çalışmasında birinci sınıf öğrencilerinin uyum puanlarının az farkla da olsa dördüncü sınıf öğrencilerinden yüksek olduğunu tespit etmiştir. Bununla birlikte Sülek Şanlı da (2015) birinci sınıf öğrencilerinin dördüncü sınıf öğrencilerinden daha yüksek uyuma sahip olduğunu ve ikinci sınıf öğrencilerinin de uyum puanlarının yüksek olduğunu belirtmiştir. Dolayısıyla her ne kadar bazı çalışmalarda ikinci sınıflar açısından aksi yönde bulgular elde edilmiş olsa da (Aktaş, 1997) ortaya çıkmış olan sonuç bir ve dördüncü sınıflar açısından tutarlıdır. İkinci sınıf düzeyinde ise değişkenlik olduğu görülmektedir. İkinci sınıf düzeyinde elde edilmiş olan bu bulgu ikinci sınıf çöküşü (sophomore slump) olarak adlandırılan durumun gerçekleşmiş olabileceğine işaret etmektedir. Araştırmalarda öğrencinin ikinci yılda yaşadığı memnuniyet düzeyinin, yaşadığı deneyimlerle önemli ölçüde aşağı indiği rapor edilmektedir (Akt. Hurtado ve diğ., 1996). Literatürde ikinci sinıfa gelen öğrencilerin kötü alışkanlıklarında (Blase ve diğ., 2009, s.303) ve psikolojik belirtilerinde (Akt. Deniz, 2014) artış olduğunu belirten bazı çalışmalar bu sorunun varlığını destekler niteliktedir. Ayrıca Piaget'in insan zihninin yeni bir kavrama uyum sağlaması konusunda ileri sürdüğü özümleme ve düzenleme (Piaget, 1955) konusundaki açıklamaları da ortaya çıkan duruma paralellik göstermektedir. Üniversiteye uyuma bu açıdan bakıldığında birey ilk yılında önceki ilişkilerinde sürdürdüğü ilişki şemalarını yeni ortama aktararak özümleme yapmakta, sonrasında bu şemalarla var olan ilişkileri yönetmekte yetersiz kaldığını görerek düzenleme yapmakta ve yeni parametrelere dayalı daha üst bir uyum düzeyine geçmektedir. Sonuç olarak öğrenciler ilk yıl kurdukları ilişkilerin derinleştiği ikinci yılda zihinlerindeki iletişim şemalarının işe yaramamasıyla birlikte bir çöküş yaşamış olabilirler. Sonrasında da zaman içerisinde kendilerini ortam dinamiklerine göre düzenlemiş ve uyum düzeylerini yeniden yukarı çıkarmış, bir başka ifadeyle düzenleme ile yeni ve daha üst bir uyum düzeyine geçiş yapmış olabilirler. 


\section{Sonuç}

Araştırma sonucuna göre kızlar genel olarak üniversiteye daha fazla uyum sağlama becerisine sahiptirler. Fakülteler arası farklılıklar açısından değerlendirme yapıldığında ise üniversiteye uyumun alt basamaklarında farkl1laşma olduğu görülmektedir. Örneğin arkadaş ilişkisinde uyum açısından eğitim, fen-edebiyat, mimarlık-mühendislik, iktisat ve ilahiyat fakültesi öğrencilerinin avantajlı olduğu görülmektedir. Tıp fakültesi öğrencileri ise arkadaş ilişkilerinde uyum açısından dezavantajlı konumdadır. Orta düzeyli akademik uyum sergileyebilme açısından ilahiyat, eğitim ve tıp fakültelerinde öğrenim görmenin avantajlı olduğu belirlenmiştir. Üniversiteye genel uyum sağlama konusunda ise ilahiyat ve tıp fakültesinde öğrenim görmenin avantajlı olduğu tespit edilmiştir. Sınıf düzeyi açısından yapılan değerlendirmelerde en dezavantajlı grubun ikinci sınıfa devam eden öğrenci grupları olduğu belirlenmiştir.

\section{Öneriler}

Sonuçlar kız öğrencilerin erkeklere oranla daha yüksek uyum becerisine sahip olduklarını göstermektedir. Dolayısıyla erkek öğrencilerin uyum sağlama açısından risk altındaki grup oldukları düşünülerek erkek öğrencilere yönelik psiko-eğitim programlarının geliştirilmesi, erkek öğrencilerin uyum sorunlarına bağlı olarak yaşayabilecekleri problemlerin önüne geçmeye katkı sağlayacaktır.

Arkadaş ilişkilerindeki uyum sorunlarının en açık olarak görüldüğü grup tıp fakültesi öğrencileridir ve her uyum düzeyinde sorun yaşamakta oldukları görülmektedir. Bu sebeple tıp fakültelerindeki öğrencilerin yoğun ders programlarına destek olabilecek sosyal faaliyetler organize edilmesi ortaya çıkabilecek kişisel sorunların engellenmesine katkı sağlayabilir. Ayrıca arkadaş ilişkilerinde uyum sorunları açısından en riskli grubun ikinci sınıf öğrencileri olduğu görülmektedir. Bu sebeple birinci sınıf öğrencilerine ikinci s1nıfta karşılaşabilecekleri tipik sorun örnekleri hakkında bilgi vermek önleyici rehberlik açısından faydalı olabilir. Bununla birlikte ikinci sınıf öğrencilerine yönelik olarak psikolojik danışma hizmetlerinin yoğunlaştırılması, ortaya çıkan sorunların büyümesine engel olma açısından yarar sağlayabilir. 
Akademik ve genel uyum açısından en uyumsuz grubun fen ve edebiyat fakültesi öğrencileri olduğu görülmektedir. Planlanacak eğitsel rehberlik çalışmalarının özellikle fen ve edebiyat fakültesi öğrencileri üzerinde yoğunlaştırılması öğrencilerin genel uyum düzeylerinde de artış sağlamaya yardımcı olabilir.

\section{Sinirlıklar}

Bu çalışmanın bazı sınırlıkları bulunmaktadır. Öncelikle çalışma kesitsel niteliktedir. Bu sebeple tek bir zaman diliminde toplanmış olan veriler, üniversiteler ve fakülteler arasında yaşanan tarihsel etkileri yansıtamayabilir. Dolayısıyla bu çalışmanın bulguları, içerisinde bulunduğu zaman diliminin şartlarıyla sınırlıdır. Gelecekte ortaya çıkabilecek olan sosyal-ekonomik ve siyasi koşullar, var olan sonuçların geçerliğini değiştirebilir. Çalışmanın diğer bir sınırlığı tek bir üniversiteden toplanmış olan verilere bağlı olmasıdır. Bu çalışmada Türkiye'nin her bölgesinden gelen öğrencilerin bulunduğu, merkezi bir üniversiteden veri toplanmıştır. Ancak farklı bölgelerdeki üniversitelerden toplanacak verilerle bölgesel koşulların etkilerinin görülebilmesi olanağ 1 elde edilecektir. Bu sebeple gelecek araştırmalarda daha geniş bir örneklemde ve daha fazla sayıda üniversiteden verilerin toplanması, Türkiye'deki Üniversiteye Uyum şartlarının belirlenmesine katkı sağlayacaktır.

\section{Çıkar Çatışması}

Yazarlar tarafından çıkar çatışmasının olmadığı rapor edilmiştir.

\section{Etik Bildirim}

Bu çalışma Helsinki Deklerasyon'u çerçevesince gerçekleştirilmiştir. Katılımcılar gönüllü olarak çalışmaya dâhil edilmiş, bilgilendirilmiş ve tüm katılımcllardan onay alınmıştır. 


\title{
EXTENDED ABSTRACT
}

\section{Which Students Are More Adjusted? Examination Of University Adjustment In Terms Of Some Demographic Factors}

\author{
Evren Erzen - Nilüfer Özabacı \\ Artvin Çoruh Üniversitesi, Yeditepe Üniversitesi
}

Students who are entitled to attend universities, whose number is increasing day by day, face various problems. Mental illnesses caused by these problems have the potential to negatively affect the academic future of students. On the other hand, students who can adapt to the social environment and academic studies of the university seem more advantageous in terms of dealing with these problems. Therefore, it is important to investigate the variables that affect the adjustment to university. For this reason, in this study, it was discussed whether the adjustment level of university students to the higher education institution they study caused differentiation according to the variables of gender, faculty and class level.

In previous studies, it is seen that different variables that affect adjustment to the university were examined. Among these studies, there are also those conducted with demographic variables. However, no study was found on individuals with different levels of adjustment to university. In this study, it was examined whether low, medium or high level of adjustment to university differs according to gender, faculty and class level. In this way, it was tried to determine in which student population the adaptation problems existed and for what reason.

In this study, the adjustment to university is dependent; the variables of gender, faculty and grade level were determined as independent variables. In this study prepared in a corelational design, 992 students selected from a universe of 21,876 registered undergraduate students enrolled in a university took part as participants. 377 of the participants are male (38\%), 615 of them are female (62\%). In addition, 223 of the participants $(22.5 \%)$ are in the first grade, 306 in the second (30.8\%), 262 in the third (26.4\%) and 201 in the fourth 
grade $(20.3 \%)$. On the basis of faculties, $170(17.1 \%)$ of the students were science and letters, 154 (15.5\%) were medical faculties, 124 (12.5\%) were engineering and architecture, $178(17.9 \%)$ were economics and administrative sciences, 193 (\%) 19.5) of theology and 173 (17.4\%) of education faculty students.

The University Adjustment Scale and personal information form developed by the researcher within the scope of the study were used in the study. The scale, which handles the adjustment skills of university students with two sub-dimensions as Friendship Adjustment and Academic Adjustment, is 5-point Likert type and has 11 items. Confirmatory factor analysis values obtained for the validity of the scale are $\chi^{2} / \mathrm{sd}=1.41$, RMSEA $=.04$, GFI $=.95$, $\mathrm{CFI}=.98$ and NNFI $=.97$. The Cronbach Alpha coefficients for the reliability of the scale are .83 for the Friendship adjustment dimension, .82 for the Academic adjustment dimension and .82 for the whole scale. The adjustment levels in the study were determined using standard deviation and average values.

The results show that female students have an advantage over male students in terms of adjustment to university. When evaluating according to the type of faculty attended, it is seen that the students of some faculties are advantageous. These advantages are as follows: In terms of friendship adjustment, faculties of education, economics and administrative sciences, theology, engineering and architecture, science and letters; theology, education and medical faculties in terms of academic adjustment; in terms of general adap-tation to the university, students of theology and medical faculties are advantageous. Analyzes in terms of grade levels show that the second grade students are in the risk group in terms of friendship adjustment, and the potential of second grade students to experience adjustment problems is higher than other grade levels.

In the data related to the gender variable, which is the first finding of the study, the reason why females are more advantageous than boys in terms of adapting to university may be that girls benefit more from social support facilities compared to boys. (Cheung and Sim, 2017; Çebi, 2009; Diaz and Bui, 2017; Kartal and Çetinkaya, 2009; Milner, Krnjacki and LaMontagne, 2016; Orman, 2016; Sayar, 2006; Sever, 2015; Yalım, 2007).

Considering the faculty variable, which is the second finding of the study, it is seen that the students of the Faculty of Theology are advantageous in 
both academic and general adaptation to the university. In addition, education faculty students seem to be advantageous in academic adjustment, and medical faculty students in general adjustment to the university. The fact that education faculty students are advantageous in terms of adaptation may be related to the low hopelessness level of the education faculty students (Şahin, 2009) and their tendency to adapt (Erdoğan, Şanll, and Şimşek Bekir, 2005). The finding that theology and education faculty students are advantageous in middle-level friendship adjustment may be related to the fact that these individuals have extroverted (McCrae and Costa, 1985) or social (Siyez, n.d .; Yeşilyaprak, n.d.) personality traits. Many different factors may have influenced the students of theology faculty to be more compatible. Higher appointment rates (MEB, 2017), higher perception of job guarantee (Nazıroğlu, Acuner, and Birinci, 2017), better motivation to close goals than distant ones (Lucariello et al., 2016; Stock and Cer-vone, 1990), participation in religious activities to increase self-esteem of the individual (Sherkat and Reed, 1992), and spirituality to increase the ability to cope with difficulties (Glenn, 2014) could be among these reasons. Advantages about appointment and job guarantee may have contributed to the high level of adjustment of medical faculty students, just like the students of the faculty of theology (Alper \& Özdemir, 2004; Köksal, Vehid, Tunçkale, Sipahioğlu and Özbal, 2014; Race, Topbaş, Çan \& Özoran. , 2001).

In the examination made according to the grade level, which is the last finding of the study, it was found that the friendship adjustment was the lowest in the second grade and the highest in the third grade. According to these results, it can be thought that the students who came to the university had a pre-perception that they were compatible due to the fact that they had not yet determined their circle of friends in the first year, and that when they interacted with a large number of friends from different backgrounds in the second year, disagreements occurred and the level of adjustment decreased suddenly. It can be said that in the third year, the level of adaptation started to increase with the gradual resolution of the relational crises, and in the fourth year, the level of adjustment was balanced at the optimum level by determining the circle of friends and staying in contact with the accepted friends, and reducing the communication with the friends who experienced the crisis. 


\section{Kaynakça / References}

Alp, D. (2019). 2019 en iyi liseler sıralaması. https://egezegen.com/egitim/turkiyenin-eniyi-liseleri-siralamasi/

Aktaş, Y. (1997). Üniversite ögrencillerïnin uyum düzeylerïnin incelenmesi: uzunlamasına bìr çalışma. Hacettepe Üniversitesi Ĕgitim Fakültesi Dergisi, 13, 107-110.

Aladağ Bayrak, Ö., ve Bülbül, T. (2013). Meslek yüksekokulu öğrencilerinin yükseköğretim yaşamına uyum düzeylerinin çeşitli değişkenlere göre incelenmesi. Sakarya University Journal of Education, 3(2), 6-20.

Alper, Z., ve Özdemir, H. (2004). Uludağ Üniversitesi Tıp Fakültesini tercih eden öğrencilerin kimi sosyo-demografik özellikleri ve mesleğe bakış açıları. Uludağ Üniversitesi Tıp Fakültesi Dergisi, 30(2), 93-96.

Altunay, A. (2010). Hemşirelik öğrencilerinin üniversiteye uyumunda problem çözmeye dayalı psikoeğitim programının etkinliğinin değerlendirilmesi.

Alver, B. (1998). Bireylerin uyum düzeyleri ile empatik becerileri arasındaki ilişkiler. Yayımlanmamış Yüksek Lisans Tezi. Erzurum, Atatürk Üniversitesi.

Arı, R. (1989). Üniversite öğrencilerinin baskın ben durumları ile bazı özlük niteliklerinin ben durumlarna, atılganlık ve uyum düzeylerine etkisi. Yayımlanmamış Doktora Tezi. Ankara, Hacettepe Üniversitesi.

Arıcı, İ., ve Tokur, B. (2017). İlahiyat fakültesi öğrencilerinin tanrı algıları ve hoşgörü eğilim düzeyleri arasındaki ilişki. Turkish Studies, 12(10), 31-48.

Arlı, E. (2013). Barınma yerinin üniversite öğrencilerinin kişisel ve sosyal gelişim ve akademik başarı üzerindeki etkilerinin odak grup görüşmesi ile incelenmesi. Journal of Higher Education and Science, 3(2), 173. https://doi.org/10.5961/jhes.2013.073

Bernier, A., Larose, S., Biovin, M., ve Soucy, N. (2004). Attachment state of mind: Implications for adjustment to college. Journal of Adolescent Research, 19(6), 783806. https://doi.org/10.1177/0743558403260096

Blase, S. L., Gilbert, A. N., Anastopoulos, A. D., Costello, E. J., Hoyle, R. H., Swartzwelder, H. S., ve Rabiner, D. L. (2009). Self-reported ADHD and adjustment in college: cross-sectional and longitudinal findings. Journal of Attention Disorders, 13(3), 297-309. https://doi.org/10.1177/1087054709334446

Bökeoğlu, Ö. Ç. (2007). Analysis of university students' views about the quality of faculty life using various variables. Ankara University Journal of Faculty of Educational Sciences, 40(2), 179-204.

Brizendine, L. (2014a). Erkek beyni (4th ed.). Say.

Brizendine, L. (2014b). Kadın beyni (12th ed.). Say. 
Bülbül, T., ve Güvendir, M. A. (2014). Üniversite birinci sinff öğrencilerinin yükseköğretim yaşamına uyum düzeylerinin incelenmesi. Eğitim Bilimleri Araștrmalan Dergisi, 4(1), 397-418.

Çebi, E. (2009). University students' attitudes toward seeking psychological help: Effects of perceived social support, psychological distress, psior help-seeking experience and gender.

Cheung, H. S., ve Sim, T. N. (2017). Social support from parents and friends for Chinese adolescents in Singapore. Youth $\mathcal{E}$ Society, 49(4), 548-564. https://doi.org/10.1177/0044118X14559502

Creswell, J. W. (2012). Educational research: Planning, conducting, and evaluating quantitative and qualitative research. In Educational Research (Vol. 3).

Darlow, V., Norvilitis, J. M., ve Schuetze, P. (2017). The relationship between helicopter parenting and adjustment to college. Journal of Child and Family Studies, 26(8), 2291-2298. https://doi.org/10.1007/s10826-017-0751-3

Deniz, A. Ç. (2014). Üniversite gençlĭğinin uyum sağlama süreçlerï: Bïr bibliyografya denemesi. Krnkkale Üniversitesi Sosyal Bilimler Dergisi, 4(1), 99-121.

Diaz, T., ve Bui, N. H. (2017). Subjective well-being in Mexican and Mexican American women: The role of acculturation, ethnic identity, gender roles, and perceived social support. Journal of Happiness Studies, 18(2), 607-624. https://doi.org/10.1007/s10902-016-9741-1

Dost, M. T. (2007). Üniversite öğrencilerinin yaşam doyumunun bazı değişkenlere göre incelenmesi. Pamukkale Üniversitesi Eğitim Fakültesi Dergisi, 22, 132-143.

Erdoğan, S., Şanll, H. S., veŞimşek Bekir, H. (2005). Gazi Üniversitesi, Eğitim Fakültesi öğrencilerinin üniversite yaşamına uyum durumları. Kastamonu Eğitim Dergisi, 13(2), 479-496.

Filiz, Z., ve Çemrek, F. (2006). Üniversite öğrencilerinin barınma sorunlarının uygunluk analizi ile incelenmesi. Eskişehir Osmangazi Üniversitesi Sosyal Bilimler Dergisi, 8(2), 207-224.

Firnci Orman, T. (2016). A study on employment worries of philosophy teacher candidates at Gazi University. Eurasian Education \& Literature Journal 2016, 5(April), 24-36.

Genç, G., Kaya, A., ve Genç, M. (2007). İnönü Üniversitesi tıp fakültesi öğrencilerinin meslek seçimini etkileyen faktörler. İnönü Üniversitesi Eğitim Fakültesi Dergisi, $8(14), 49-63$.

Glenn, C. T. B. (2014). A bridge over troubled waters: Spirituality and resilience with emerging adult childhood trauma survivors. Journal of Spirituality in Mental Health, 16(1), 37-50. https://doi.org/10.1080/19349637.2014.864543 
Gökkaya, M. (2016). Bir grup üniversite öğrencisinde sosyal kaygı, depresyon ve anne-baba tutumlan ile mükemmeliyetçilik eğilimleri arasındaki ilişkinin değerlendirilmesi.

Gómez, E., Alfredo, U., ve Glass, C. R. (2014). International student adjustment to college: Social networks, acculturation, and leisure. Journal of Park and Recreation Administration, 32(1), 7-25.

Güçlü, N. (1995). Yabancı öğrencilerin uyum problemleri. Hacettepe Üniversitesi Eğitim Fakültesi Dergisi, 16, 101-110.

Gülücü, H. (2017). Üniversite öğrencilerinin meslek ve kariyer seçimi ile kişilik özellikleri arasındaki ilişki: İktisadi ve idari bilimler fakültesi öğrencileri üzerine bir araştırma.

Halamandaris, K. F., ve Power, K. G. (1997). Individual differences, dysfunctional attitudes, and social support: A study of the psychosocial adjustment to university life of home students. Personality and Individual Differences, 22(I), 93104. https://doi.org/10.1016/S0191-8869(96)00175-4

Hinkle, S. E. . (2004). Making the transition: The adjustmen experiences of first-year students attending a pre-college academic.

Hum, E. S. (Emily), ve Falci, C. (2016). Gender differences in social support and physical health. UCARE Research Products. içinde https://doi.org/10.1037//02786133.10.2.102

Hurtado, S., Carter, D. F., ve Spuler, A. (1996). Latino student transition to college: Assessing difficulties and factors in successful college adjustment. Research in Higher Education, 37(2), 135-157. https://doi.org/10.1007/BF01730113

Hyppölä, H., Kumpusalo, E., Neittaanmäki, L., Mattila, K., Virjo, I., Kujala, S., Luhtala, R., Halila, H., ve Isokoski, M. (1998). Becoming a doctor - Was it the wrong career choice? Social Science and Medicine, 47(9), 1383-1387. https://doi.org/10.1016/S0277-9536(98)00208-1

İkiz, F. E., Asıcı, E., Savcı, M., ve Yörük, C. (2015). Problemli internet kullanımı ile üniversite yaşamına uyum ilişkisi. Bartın Ünïversitesi Eğitim Fakültesi Dergisi, 4(1), 34-50. https://doi.org/10.14686/buefad.v4i1.1082000151

İhami, B., ve Oral, B. (2011). Self-efficacy perceptions regarding teaching profession: The case of faculty of science, letters, theology and fine arts graduates attending pedagogic formation program. İnönü Üniveristesi Eğitim Fakültesi Dergisi, 12(3), 1-18.

Kalsner, L., ve Pistole, M. C. (2015). College adjustment in a multiethnic sample: Attachment, separation-individuation, and ethnic identity. Journal of College Student Development, 44(1), 92-109. https://doi.org/10.1353/csd.2003.0006 
Karahan, F., Sardoğan, M. E., Özkamalı, E., ve Dicle, A. N. (1999). Üniversite 1. sinff öğrencilerinin üniversiteye uyum düzeylerinin sosyokültürel etkinlikler açısından incelenmesi. Çukurova Üniversitesi Ĕ̆itim Fakültesi, 2(30), 63-72.

Karahan, F., Sardoğan, M., Özkamall, E., ve Dicle, A. N. (2005). Üniversite öğrencilerinin üniversite yaşamına uyum düzeylerinin denetim odağı ve atılganlık düzeyleri açısından incelenmesi. Dokuz Eylül Üniversitesi Buca Eğitim Fakültesi Dergisi, 18, 6-15.

Kartal, A., ve Çetinkaya, B. (2009). Yüksekokul öğrencilerinin algilanan sosyal destek durumları ve sosyal desteği etkileyen faktörler. Firat Sağllk Hizmetleri Dergisi, $4(12), 3-20$.

Keskin, M. Y. (2003). Furat Üniversitesi ilahiyat fakültesi öğrencilerinin sosyokültürülen ve ekonomik tabanı. Firat Üniversitesi Sosyal Bilimler Dergisi, 13(1), 309-330.

Keskiner, P. (2012). The relationship between parental acceptance and children's psychological adjustment in the context of parental power and prestige in a Turkish sample. https://doi.org/10.1007/s13398-014-0173-7.2

Köksal, S., Vehid, S., Tunçkale, A., Sipahioğlu, F., ve Özbal, A. N. (2014). Cerrahpaşa Tip Fakültesi öğrencilerinin tıp eğitimi ve mezuniyet sonrası ile ilgili tutumları. Elektronik Cerrahpaşa Tip Dergisi, 30(4), 1-11.

Leong, F. T. L., Bonz, M. H., Zachar, P., Leong, F. T. L., Bonz, M. H., ve Zachar, P. (2017). Coping styles as predictors of college adjustment among freshmen coping styles as predictors of college adjustment among freshmen. Counselling Psychology Quarterly, 5070(1). https://doi.org/10.1080/09515079708254173

Lodico, M. G., Spaulding, D. T., ve Voegtle, K. H. (2006). Methods in educational research: From theory to practice. http://books.google.com/books?id=G9D81mh9xCAC\&pgis=1

Lucariello, J. M., Nastasi, B. K., Anderman, E. M., Dwyer, C., Ormiston, H., ve Skiba, R. (2016). Science supports education: The behavioral research base for psychology's top 20 principles for enhancing teaching and learning. Mind, Brain, and Education, 10(1), 55-67. https://doi.org/10.1111/mbe.12099

McCrae, R. R., ve Costa, P. T. (1985). Updating Norman's “Adequate Taxonomy": Intelligence and personality dimensions in natural language and in questionnaires. Journal of Personality and Social Psychology, 49(3), 710-721. https://doi.org/10.1037/0022-3514.49.3.710

MEB. (2017). 2017 yılı sözleşmeli öğretmenlik sözlü smavında başarlı olan adaylarn öğretmen atama sonuçları ve taban puanlar. http://ikgm.meb.gov.tr/meb_iys_dosyalar/2017_07/19201403_2017_1_S_ALAN_BAZLI_TABAN_PUANLAR.zip 
Mercan, Ç. S., ve Yıldız, S. A. (2011). Eğitìm fakültesï bïrincì sınıf öğrencilerìnìn üniversiteye uyum düzeylerïnin farklı değişkenler açısından incelenmesi. Hasan Âli Yücel Ĕ̆itim Fakültesi Dergisi, 8(2), 135-154.

Milner, A., Krnjacki, L., ve LaMontagne, A. D. (2016). Age and gender differences in the influence of social support on mental health: a longitudinal fixed-effects analysis using 13 annual waves of the HILDA cohort. Public Health, 140, 172178. https://doi.org/10.1016/j.puhe.2016.06.029

Murray-Harvey, R., ve Slee, P. T. (2010). School and home relationships and their impact on school bullying. School Psychology International, 31(3), 271-295. https://doi.org/10.1177/0143034310366206

Nazıroğlu, B., Acuner, H. Y., ve Birinci, A. (2017). DKAB ve İHL meslek dersleri öğretmenlerinin insan doğasına ilişkin tutumları. Hitit University Journal of Social Sciences Institute, Year 10(1), 471-502. http://dx.doi.org/ 10.17218/hititsosbil. 285112

Olmstead, S. B., Roberson, P. N. E., ve Fincham, F. D. (2012). Early psychological distress is a precursor to college men's later academic and social adjustment. College Student Journal, 53-59.

Orman, Y. (2016). Lise öğrencilerinde algılanan sosyal destek ile psikolojik dayanıklılı arasındaki ilişkinin incelenmesi: Başakşehir Örneŏi.

Özdel, L., Bostancı, M., Özdel, O., ve Oğuzhanoğlu, N. K. (2002). Üniversite öğrencilerinde depresif belirtiler ve sosyodemografik özelliklerle ilişkisi. Anadolu Psikiyatri Dergisi, 3, 155-161.

Öztemel, K. (2010). Teknik eğitim fakültesi öğrencilerinin uyum düzeylerinin incelenmesi. Politeknik Dergisi, 13(4), 319-325.

Piaget, J. (1955). The construction of reality in the child. Psychological Bulletin, 52(1955), 526-528. https://doi.org/10.1037/h0039645

Reyes, W. (2011). Ethnic identity, cultural congruity, and styles as factors infulencing college adjustment among first and second year Latino students.

Rienties, B., Beausaert, S., Grohnert, T., Niemantsverdriet, S., \& Kommers, P. (2012). Understanding academic performance of international students: The role of ethnicity, academic and social integration. Higher Education, 63(6), 685-700. https://doi.org/10.1007/s10734-011-9468-1

Sadıkoğlu, G., Özçakır, A., Uncu, Y., Alper, Z., Özdemir, H., ve Bilgel, N. (2003). Uludağ Üniversitesi Tıp Fakültesi'ni 2001 yılında tercih eden öğrencilerin sosyo-ekonomik düzeyleri. Türkiye Klinikleri Tıp Bilimleri Dergisi, 23(2), 14-17. 
Şahin, C. (2009). Eğitim fakültesinde öğrenim gören öğrencilerin umutsuzluk düzeyleri. Selçuk Üniversitesi Ahmet Keleşoğlu Eğitim Fakültesi Dergisi, 27, 271286.

Şahin, C., ve Tunçel, M. (2008). Sınıf öğretmenliği ve beden eğitimi öğretmenliğinde öğrenim gören öğrencilerin psikososyal uyum düzeylerinin incelenmesi. Ahi Evran Üniversitesi Kurşehir Ĕ̈̆itim Fakültesi, 9(2), 45-50.

Sancar, S. (2014). Türk modernleşmesinin cinsiyeti: Erkekler devlet, kadinlar aile kurar (Üçüncü). İletişim.

Sánchez, B., Colón, Y., ve Esparza, P. (2005). The role of sense of school belonging and gender in the academic adjustment of Latino adolescents. Journal of Youth and Adolescence, 34(6), 619-628. https://doi.org/10.1007/s10964-005-8950-4

Şanlı Kula, K., ve Saraç, T. (2017). Fen edebiyat fakültesi öğrencilerinin kaygı ve umutsuzluklarını incelenmesi. Çukurova Üniversitesi Sosyal Bilimler Enstitüsü Dergisi, 26(2), 14-29.

Sayar, M. (2006). A longitudinal study of the relationship between social support and psychological support and psychological well-being of adolescents from low socioeconomic status.

Sever, G. (2015). Lise öğrencilerinìn madde kullanma eğilimlerinin algilanan sosyal destek ve riskli dauranişlarla ilişkisinin incelenmesi:

Sevüktekin, M., Nargeleçekenler, M., ve Çetin, I. (2012). Uludağ Üniversitesi öğrencilerinin sosyo-ekonomik profil araştırması. Uludağ Üniversitesi İ̈BF Dergisi, XXXI(2), 99-128.

Sherkat, D. E. ve Reed, M. D. (1992). The effects of religion and social support on selfesteem and depression among the suddenly bereaved. Social Indicators Research, 26(3), 259-275.

Siyez, D. (n.d.). John L. Holland ve kişilik tipleri. Retrieved August 4, 2019, from kisi.deu.edu.tr/didem.siyez/john_holland.ppt

Sönmez, Ö. A. (2019). Üniversite öğrencilerinin tolerans düzeylerinin farklı değişkenlerle ilişkisi. Selçuk Üniversitesi Sosyal Bilimler Enstitüsü Dergisi, 41, 302-316.

Stock, J., \& Cervone, D. (1990). Proximal goal-setting and self-regulatory processes. Cognitive Therapy and Research, 14(5), 483-498. https://doi.org/10.1007/BF01172969

Sülek Şanlı, G. (2015). Üniversite öğrencilerinin psikososyal gelişim düzeyinin üniversiteye uyumla ilişkisi. 
Thomas, D. M., Love, K. M., Roan-Belle, C., Tyler, K. M., Brown, C. L., ve Garriott, P. O. (2016). Self-efficacy, motivation, and academic adjustment among African American women attending institutions of higher education. The Journal of Negro Education, 78(2), 159-171.

Türk, E. (2018). Fen lisesi öğrencileri üstün yetenekli mi? Milli Ĕ̆itim, 1, 437-444.

Vedel, A. (2016). Big Five personality group differences across academic majors: A systematic review. Personality and Individual Differences, 92, 1-10. https://doi.org/10.1016/j.paid.2015.12.011

Yalım, D. (2007). Üniversite birinci sını öğrencilerinin uyumu: Psikolojik sağlamlık, başa çıma, iyimserlik ve cinsiyetin rolü.

Yarış, F., Topbaş, M., Çan, G., ve Özoran, Y. (2001). Karadeniz Teknik Üniversitesi tıp fakültesi öğrencilerinin tıp eğitimi hakkındaki düşünceleri. Journal of Experimental and Clinical Medicine, 18(4), 233-241.

Yeşilyaprak, B. (n.d.). Özellik - Faktör ve Holland'in kuramları. http://birimler.dpu.edu.tr/app/views/panel/ckfinder/userfiles/74/files/belgeler/meslekigelisimkuramlari.pdf

YÖK. (2019a). Yükseköğretim kontenjan, tercih ve yerleşme istatistikleri (2018 YKS). https://yokatlas.yok.gov.tr/meslek-lisans.php?b=10206

YÖK. (2019b). Yükseköğretim kontenjan, tercih ve yerleşme istatistikleri (2018 YKS). https://yokatlas.yok.gov.tr/meslek-lisans.php?b=10098

Yusoff, Y. M. (2012). Self-Efficacy, perceived social support, and psychological adjustment in international undergraduate students in a public higher education Institution in Malaysia. Journal of Studies in International Education, 16(4), 353371. https://doi.org/10.1177/1028315311408914

\section{Kaynakça Bilgisi / Citation Information}

Erzen, E. ve Özabacı, N. (2021). Hangi öğrenciler daha uyumlu? üniversiteye uyumun bazı demografik faktörlere göre incelenmesi. OPUSUluslararası Toplum Araştırmaları Dergisi, 17(33), 447-476. DOI: 10.26466/opus.773534 